\title{
Revealing the Agency Cost, Management Behavior in the Practice of Tri Hita Karana Culture (A Study At LPD Of Pakraman Village In Denpasar Bali)
}

\author{
Made Sudarma \\ (Lecturer Doctorate Program in Management Science, Post Graduate Faculty of Economics and Business, \\ Brawijaya University Malang; HP: 0811361349)
}

\begin{abstract}
The research aims to dig and explain the practice of Tri Hita Karana (THK) cultural values implemented at LPD in relation to the agency costs. Ethnomethodology method is used in the research to understand principle's and agent's behavior with respect to THK cultural values. Research result shows that indexicality of THK cultural values such as parahyangan, pawongan and palemahan form reflexivity of agency cost items. The reflexivity of agency cost of parahyangan raises cost of pura development, ceremonial and donation for ceremonies. The reflexivity of agency cost of pawongan raises cost of education, health, ngabennyekah and funeral charity. The reflexivity of agency cost of palemahan raises cost of market, village hall, and sport facilities development, and beach arrangement. THK values and agency cost are important aspects to be considered in company management in order to maintain a balance relationship between God, Human and Environment to create harmonization in an organization.
\end{abstract}

Keywords : Agency cost, Tri Hita Karana, LPD, Harmony

\section{Introduction}

The role of culture in the last decade has gained many attentions from economic experts since economic interaction cannot be separated from cultures owned by various countries in the world. The contribution of cultures in understanding economic phenomenon shows that cultural hypotheses are important to explain fundamental economic problems such as saving level and international trade (Guiso et al, 2008,2009) [10] [11]. Another view states by Tabellini (2008) [33] that culture is the key determinant of economic development and empirical studies about culture also brings consequences in financial literature, capital market phenomenon, company capital structure (Chui et al, 2002) [3], cash possession levels (Ramirez and Tadasse, 2009) [25], return at momentum strategies (Chui et al, 2010) [4] and industrial development in information mix (Huang, 2008) [15].

Hofstede (1994) [13] defines culture as "collective thinking programming that differentiates members of one group or people category to another". Many cultural factors are covered in this definition, including legal environment, tax environment, economic systems and technological capabilities. These cultural factors are covered by Broek and Webb in their study about cultural groups identification. Two countries in one group will have the same national culture. Two countries from different group will have different national culture. Another cultural classification scheme offered by Hofstede (1990) [12] identifies four dimensions of national culture: individualism, power gap, masculinity and uncertainty avoidance.

Based on Hofstede's (1990) [12] cultural concept, Indonesia is belong to a country with high power level, high uncertainty avoidance and high collectivity and these will characterize the journey of a company in this country. Bali is part of Indonesia and it has strong local culture in daily life. One of local culture, which is the foundation to form a village in Bali, refers to harmonization between human and God (parahyangan), among humans (pawongan) and human with environment (palemahan). These three cultural concept known as Tri Hita Karana (THK). THK cultural concept becomes organizational culture in Bali. It is proven with an annual competition held in Bali for hospitality companies in the implementation of those three components.

Cultural concept cannot be separated from THK cultural values that become a bond in villages at Bali; therefore, a company established by Balinese, especially in the village, should implement these values. One of companies owned by Balinese is Village Credit Institution (Lembaga Perkreditan Desa/LPD). It gives credit service to the villagers and maintains cultural preservation (Perda No. 8, 2002) [22]. Through LPD, THK cultural concept is implemented affirmatively and real, and is made as a tool by managers in conducting their activities.

LPD activities have been arranged in awig-awig (rules) of traditional village (desa adat). One of the rules states that LPD is manage by a leader assigned by traditional village to run the company based on rules determined by the traditional village. Separation between owner and manager in LPD, viewed from modern financial management, causes vulnerability for agency problems to be occurred as developed by Jensen and 
Meckling (1976) [17]. It is because human is considered to have opportunistic and rationalistic characteristics in their action or in doing activities in a company. These two assumptions clarified by Eisenthardt (1989) [6] that human is self-interest, has bounded rationality about future perception, and a risk-averse.

It is interesting to reveal and explain the vulnerability for agency conflict at LPD if it is approached with agency theory with standardized assumptions, while there exist cultural practice emphasizing on harmony relationship with God, human and environment to create harmonization. The emphasize on these three relationships can be analogue into agency theory framework, where God is the principle and LPD is the agent (parahyangan), because it is believed that the existence of LPD is a gift from God; therefore any gain from the company is set aside to give to God. The same is implemented by LPD as the principle and environment as the agent (palemahan) by involves in village environment arrangement. The last relationship is LPD as the principle and LPD's managers as the agent (pawongan) through the fulfillment of rights and obligation of LPD's employees.

\section{II.1Organizational Culture}

\section{Theoretical Study}

Various definitions on organizational culture have been stated in the context of anthropology, organizational psychology and management theory. Deal and Kennedy (1982) [5] explain that organizational culture is a dominant value followed by an organization. Kotter and Heskett $(1992,1997)$ [20] [21] state that organizational culture is a behavior pattern or style that encourage new member to follow it. Frost (1985) in Kotler and Heskett (1997) [21] suggest the importance of organizational culture for organizational members because it is about symbol, ritual, myth, story and legend on events interpretation, idea and experience influenced and formed by a group of people where they interact to each other.

Hofstede (2001) [14] chooses to define culture as a thinking pattern, feeling and action of a social group that differentiate the group from other social groups. Siagian (2002) [31] defines organizational culture as refer to a system of common sense followed by organizational members that differentiate the company to other companies. It is also states that organizational culture is one of important variables for a leader since organizational culture reflects recognized values and guidance for organizational member. In addition, Robbins $(2003,2005)$ [27] [28] defines organizational culture as a shared perception followed by organizational members and it becomes a system of shared meaning.

\section{II.2THK Cultural Concept and Organizational Concept}

THK culture is a culture derived from local wisdom. According to Sobirin (2007) [32], national culture shaped by different reason since the emergence of a country has different background. Therefore, various factors (such as ethnic, economic, politic, religion or language) contribute in the shape of national culture. Schein (2004) [30] states that cultural organization is based on three levels: first is an artifact, something modified by human for certain purpose that visible from organizational structure and process. Artifact is something that we can easily captured when we entering an organization because it is related to what we seen, heard and felt when we inside an organization environment. Second, espoused beliefs and values, which are supporting values consists of strategies, goals, and basic philosophies the organization has that can be understood if we go deeper into the organization and live longer in the organization. These supporting values usually stated in writing and become guidance for every step taken by organization members. Third, underlying basic assumptions, which are implicit assumptions that mutually believed. Values, beliefs, and assumptions used by the founders are considered important for the success of an organization.

Model developed by Schein (2004) [30] helps in organizing cultural puzzle where artifact is the easiest to be observed, while basic assumptions need to be concluded. To understand behavior and belief meant by members, basic assumptions should be raised. Basic assumptions are the most difficult level because it is beyond awareness. Schein's (2004) [30] model can be applied both to national and organizational cultures. Culture is always conceptioned as the result of patterned relationship from various elements, such as technology, belief, values, and rules and serves as guidance. THK is the product of human behavior that subjective and interpretative in nature. Therefore, symbols will be built by subjective understanding related to phenomenon having objective consequences. Regarding THK, parahyangan is analogue with value sub-system, pawongan with social sub-system and palemahan with artifacts sub-system. Interrelationship among the sub-systems in THK concept can be described as follow. 
Figure 1. THK concept as Cultural System

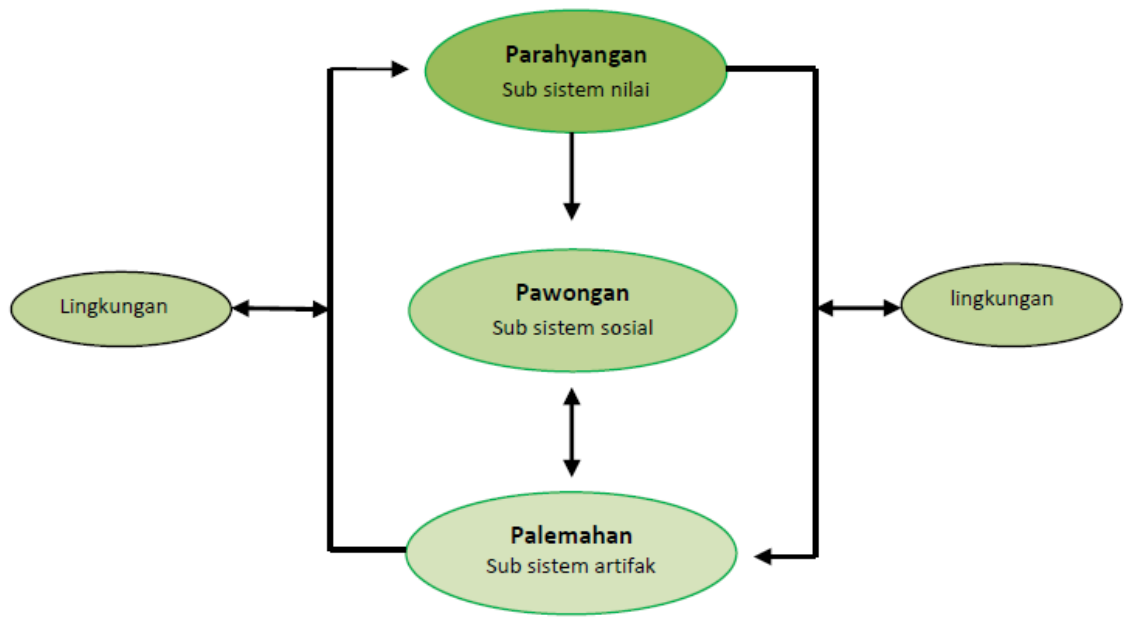

Source: Windia, 2007

As we can see in Figure 1, cultural elements; artifacts, espouse values, and basic assumptions (Schein, 2004) [30] and thinking pattern, social, and artifact sub-systems (Koentjaraningrat, 2005) [19] are reflected in THK cultural elements, parahyangan, pawongan and palemahan. Therefore, values contained in THK culture have been used as a value order used as a handbook for organizational members in performing their obligation and to behave. Table 1 describes the matrix form of comparison between cultural theory from Hofstede, Schein, and Koentjaraninggrat, and Tri Hita Karana (THK) culture.

Table 1

Comparison between Cultural Theories from Hofstede, Schein, and Koentjaraninggrat, and THK

\begin{tabular}{||c||c|c|c|}
\hline THK & $\begin{array}{c}\text { Koentjara- } \\
\text { ningrat }\end{array}$ & Schein & Hofstede \\
\hline Parahyangan & Sistem nilai & $\begin{array}{c}\text { Basic } \\
\text { assumption }\end{array}$ & Uncertaity avoidance \\
\hline Pawongan & Sistem sosial & Value system & $\begin{array}{c}\text { Individualism \& } \\
\text { Collectivism } \\
\text { Power distance } \\
\text { Maskulinity \& feminity }\end{array}$ \\
\hline Palemahan & $\begin{array}{c}\text { Sistem } \\
\text { kebendaan }\end{array}$ & Artifact & $\begin{array}{c}\text { Short term \& long } \\
\text { term }\end{array}$ \\
\hline \hline
\end{tabular}

Source: Riana (2010) [26]

Based on Table 1, it can be explained that characteristic and cultural dimensions of THK are reflected in the dimensions of several cultural concept (Koentjaraninggrat, Schein, and Hofstede). Therefore, THK cultural concept is a cultural concept where values contained in it has characterized various communities' lives especially in Bali, including when they are conducting business activities; therefore, it can be categorized as organizational culture.

\section{II.3 Agency Theory}

The agency theory is related to "agency problem" occurring when there exist an agency relationship. In agency relationship, one party (principle) delegates the decisions and/or work to another party (agent). The agency problem occurs because the agent has different goals than the principle's goals (Jensen and Meckling, 1976 [17]; Ross, 1973) [29]. The premise of agency theory is that agents is having self-interest, risk averse and rational actors who always try to give little effort (moral hazard) and project higher capability and skill compare to they actually have (reverse selection). Agency theory tries to solve two agency problems. The first problem is supervising problem occurs when principle is unable to verify whether the agent behaves appropriately. The second problem is related to risk sharing (especially in the case of profit-based control) that occurs when principle and agent have different attitude toward risk (Eisenhardt, 1989) [6]. Agency theory is divided into two groups (Eisenhardt 1989[6], Jensen 1983). The first group, positivist research, has focused on identifies situation where principle and agents may have contradictive goals, and explains the governance mechanism limiting the 
self-interest behavior of an agent" (Eisenhardt 1989, p. 59) [6]. Positivist agency research almost only related to goals conflict between owner (shareholder) and manager. In line with positivist, Jensen and Meckling (1976) [17] tested on how equity ownership by management helps harmonizing managers' goals to the owners'; Fama (1980) [7] tested the role of capital and employment markets in controlling manager's behavior; Fama and Jensen $(1983,1985)$ ) [8] [9] tested the role of Board of Directors as supervisory tool. The second group, principle-agent research, focused on general theory of principle-agent relationship applicable in the relationship between employer-employee, attorney-client, and buyer-supplier. According to Eisenhardt (1989) [6], "positivist" theory identifies various contract alternatives and principle-agent theory indicates which contract is the most efficient in the levels of result uncertainty, risk averse, information and other varying variable". Agency theory has developed beyond the real positivist domain and has been used by researchers (principleagent) in several disciplines to study problems occur in agency-like relationship, for example, relationship between superior-subordinate. The broader use of agency theories (positivist or principle-agent) can be related to the attractiveness of model regarding to it assumptions about people (such as self-interest, bounded rationality, risk averse), organization (such as, goals conflict among the members) and information (such as, a commodity or supervisory tools) (Eisenhardt, 1989) [6]. Agency theory tries to describe human behavior in an organization. Jensen $(1983,1992)$ [18] [16] explained agency theory as a strong organizational theory.

\section{III.1 Ethnomethodology}

\section{Research Method}

Ethnomethodology is efforts to describe and understand the society in the daily life, such as how is their interaction pattern, way of thinking, feeling and way of talking (Bungin, 2007: 170) [1]. The term of ethnomethodology first proposed by Garfinkel in 1967 refers to the study of the ways in which people make sense of their social world (Poore, 2000) [23]. According to Garfinkel, ethnomethodology research assumes that social regularity is an illusion, it looks like regulated but actually is a mess. Social regularity is formed in social actors' mind as a set of impression and experiences that should be organized by those actors in a full pattern.

Sarantakos (2006) [24] explained about criteria used by this type of research, among others: researchers should involve socially as participant in a group or community they studied; using eclectic approach, which is using various tools to get clarity and deepness of the construct they studied; long term observation and adopt natural approach in his/her observation. Natural approach means portraying society group in its real environment instead of artificial environment. The aim of ethnomethodology study is to understand sociocultural system and how society interprets their world, which is in this study is management behavior related to agency cost and Tri Hita Karana. Therefore, ethnomethodology interpretation in this interpretive paradigm will cover aspects of parahyangan (the harmonization relationship between human and God), pawongan (the harmonization relationship among humans) and pelemahan (the harmonization relationship between human and environment) studied from the LPD's management reflected in the agency cost.

Burrell and Morgan (1979) [2] explained two important aspects in ethnomethodology that should be performed in data analysis. First, indexicality, which is an effort to present every form of written practice that become a guidance followed by the actors. Second, reflexivity, which is a study on every form of practice, in this case LPD Kedongan, forming based on experience and interaction. These two aspects will be an important analysis points for this research.

\section{III.2 Informant and Research Site}

Informant in this study will consist of LPD leaders and some of LPD staff at Kedongan cultural village. This LPD established on September 9, 1999, supported by six banjar adat and agencies. Population of the village is 5.097 people in 2009, 2.512 are men and 2.585 are women. The start-up capital is Rp. 4.600.000, which is Rp. 2.000.000 gained First Level of Local Government of Bali and Rp. 2.600.000 gained from Second Level of Local Government of Badung.

This LPD received award as the best LPD in the First Level of Bali Province in 1999 with such product as Tabungan Investasi Desa/Tindak (village investment saving), Tabungan Beasiswa / Tabe (scholarship saving), Simpanan Upacara Adat/Sipadat (traditional ceremonies saving), Tabungan Sukarela (voluntary saving), Simpanan Berjangka (deposit), Kredit Modal Kerja (work capital credit), Kredit Investasi (investment credit) and Kredit Konsumtif (consumptive credit).

Currently, the capital is Rp. 16.5 billion with profit of 4.1 billion gained from 8.463 customers from six banjar adat and agency. This LPD also in health category since it is within the range of 81-100 determined by Bank Pembangunan Daerah/BPD (Regional Development Bank) as LPD supervisory institution.

\section{Result And Discussion}

The establishment of LPD has strategic aims. In addition to economic reason, it is also put in the frame of social and cultural aspect development, especially in the effort to maintain the sustainability of custom, 
culture and religion of Kedongan society. Indexicality study on the management practice of LPD Kedongan implies its active role in implementing three aspects in life management that bring happiness called Tri Hita Karana. These three aspects are parahyangan (the harmonization relationship between human and God), pawongan (the harmonization relationship among humans) and pelemahan (the harmonization relationship between human and environment). These harmonious interactions are the result of experience and understanding of actors in LPD Kedongan and the reflectivity forms of the relationship between principle and agent occur in agency costs at the LPD.

\section{"Parahyangan"} as stated below:

The implementation of parahyangan aspect of THK is described through a dialogue with LPD leader

"aspek parahyangan niki polih perhatian lebih santukan titiang orang Bali percaya yen parahyangan becik sampun janten ngewetuang kerahayuan mempengaruhi aspek lain, nike mawinang tiang ngewangun Pura Dalem, Pura Segara, Pura Penataran dan Pura Gedong Ratu Aуu " (Manuskrip 1.1)

("The aspect of Parahyangan gains more attention because I am a Balinese who believes that if I have a good relationship to God, surely it will give a good vibration to other aspects. Thus, LPD builds Pura Dalem, Pura Segara, Pura Penataran and Pura Gedong Ratu Ayu")

The statement means that the way of LPD to keep harmonious relationship with God is by building a pura (temple), since they believe that it will gives way to advancement and success in the future. Thus, this relationship is becoming special interest in LPD. The building of pura is the cost of agency relationship given to the principal (God) in order to preserve harmony. God castled through the building of Pura so that the vibration of pura is believed will influence peoples' behavior in order to create harmony.

Related to the the building of pura, LPD cannot be separated with its activities to look for proper persons, conducting ceremonies before the building begins, as well as landscaping the environment of the pura harmoniously; therefore the implementation of three aspects of harmonious cannot be separated.

Another thing conveyed by Head of LPD considering the implementation of Parahyangan concept is:

"Tios nike LPD sampun ngelaksanayang piodalan di Pura ring wewidangan Kedongan tur rauh ring sekehaa Hyang lan Dadia. LPD sejak 2008 sampun ngicen punia keanggen ngelaksanayang upacara ring banjar-bajar akeh nyane 30 juta" (Manuskrip 1.2 dan 1.3)

("in addition, LPD also funds ceremonial activities in pura available in Kedongan village up to pura by family as well as funding ceremonies in many banjars as much as 30 million rupiahs")

The meaning of above utterance is that in order to keep harmonious relationship with God, LPD spends money to funds the ritual or ceremonial as the implementation of bhakti. If these costs converted into agency cost, it is the cost for the principle; therefore, the manuscript above can be summarized in Table 2.

Table 2

Mapping of Agency Costs in Parahyangan Dimension

\begin{tabular}{|l|l|}
\hline $\begin{array}{l}\text { Agency cost items } \\
\text { (Refexivity study) }\end{array}$ & $\begin{array}{l}\text { Dimension } \\
\text { (Indexicality study) }\end{array}$ \\
\hline 1.1 Cost for Pura Development (praying site) & Parahyangan \\
1.2 Cost for ceremonies & \\
1.3 Donation for ceremonies & \\
\hline
\end{tabular}

\section{"Pawongan"}

Pawongan aspect emphasizes harmonious relationship with human so that LPD as the principal and human or societies as the agents try to perform cultural values in every of their activity. Thus, Head of LPD suggests as follow:

"LPD sampun ngerancang tabungan biasiswa tur ngicen murid biasiswa sane berprestasi. Sedurunge murid-murid nike di tes, sire sane polih nilai becik nike ke icen, sios nike ngicen sane nenten mampu tios nike ngewangun TK” (Manuskrip 2.1) 
(LPD has arranged saving accounts for scholarship and already gave scholarship to outstanding students through such a test. Who got the highest mark; he/she will receive the scholarship. We also give aid to underprivileged students as well as building kindergarten)

The meaning of the utterance above is that LPD, in order to keep harmonious relationship with human, has spent educational fund in form of scholarship for academically outstanding students as well as they who come from poor families. Furthermore, LPD has also built kindergarten as an educational place for the people of Kedongan Village.

The researcher tries to find out about other activities, and Head of LPD suggests as follow:

"Ring LPD Desa Kedonganan sane mangkin sampun menjalin hubungan sareng rumah sakit jagi ngicen para mangku, prajuru lan karyawan LPD pelayanan kesehatan, tiosan nike tiang ngicen santuanan kematian, ngaben masal lan nyekah masal" (Manuskrip 2.2,2.3,2.4)

(at this time, LPD Kedongan has interlace cooperation with hospitals to give medical services to the staffs, pemangku and employees of LPD. Other activities has also been done such as funeral charity, carrying out nyekah and ngaben ceremony)

LPD has given example of care on peoples' suffering. That is why they do not mind to spend money for the health of their employees, staffs, and holders (preacher). Another important thing is that they also fund the ngaben and nyekah ceremonies. These activities give lesson on tatwam asi, olas asih, love and respect diversities amongst creatures in this world. This condition is expected to keep the world stays in harmony. Explanation on pawongan dimension and cost expended sincerely by LPD can be summarized in Table 3 .

Table 3

Mapping of Agency Costs in Pawongan Dimension

\begin{tabular}{|l|c|}
\hline $\begin{array}{l}\text { Agency cost items } \\
\text { (Reflexivity study) }\end{array}$ & $\begin{array}{l}\text { Dimension } \\
\text { (Indexicality study) }\end{array}$ \\
\hline 2.1 Educational Cost & Pawongan \\
2.2 Health care cost & \\
2.3 Cost for Ngaben and Nyekah & \\
2.4 Funeral charity & \\
\hline
\end{tabular}

\section{“Palemahan”}

Palemahan aspect emphasizes harmony with surrounding environment where the business exists. Several activities have been carried out related to this aspect as conveyed by Mr. Ketut, one of the staff at LPD as follow:

"LPD iriki sampun ngewangun pasar Desa Adat, pembangunan balai desa lan sarana olah raga. Prebiya 1,3 milyar. Tetujon ipun mangde presida ekonomi desane maju kewangun pasar, tur kramane mangde becik jagi ngelaksanayang paruman lan kegiatan tiosan”( Manuskrip $3.1,3.2,3.3)$

(here, LPD has helped the creation of Desa Adat's Market, built Village Hall and Sport Facilities which cost 1,3 billion rupiahs. The purpose of these projects is to foster village's economy and provide people with a convenience place to carry out meetings and other activities.)

LPD has carried out activities in order to keep environmental harmony which costs 1,3 billion rupiahs. This amount is used to fund the building of market, village patio and sport facilities that it is believed can provide harmony in doing business. Another great thing is when they landscaping Kedonganan Beach that was dirty. Now it looks tidier with many fish stalls opened, so it now becomes a culinary destination in Bali. It is stated by LPD supervisor as follow:

"Program pelemahan ngewangun tur nata warung-warung ikan ring pantai, ngicen kredit 12 milyar ke enam banjar, santukan mangkin pengelolaanyane desa adat dumun warge tiosan sane ngelola”. (Manuskrip 3.4)

(Program on palemahan has been done by arranging fish stalls along the kedongan beach, as well as giving credit as much as 12 billion rupiahs to six banjars. The management of those stalls was held by the outsiders; now they have been took over by desa adat) 
The arrangement of beach stalls generates vibration of beauty, as well as fostering society's economy and in turn fostering the advancement of LPD itself. LPD Kedongan has many contributions and can be summarized in Table 4, consists of cost for building market, village hall, and sport facilities, and beach arrangement. All cost spent sincerely for agents in the surrounding environment give unique characteristic in Kedongan Village which make this village famous as culinary village with a very tasteful roasted fish.

Table 4

Mapping of Agency Costs in Palemahan Dimensions

\begin{tabular}{|l|l|}
\hline $\begin{array}{l}\text { Agency cost items } \\
\text { (Refectvity study) }\end{array}$ & $\begin{array}{l}\text { Dimension } \\
\text { (Indexicality study) }\end{array}$ \\
\hline 2.1 Cost for Market Development & Palemahan \\
2.2 Cos for Village Hall Development & \\
2.3 Cost for Sport Facilities Development & \\
2.4 Cost for Beach Arrangement & \\
\hline
\end{tabular}

LPD has played its agency function through the spending of costs, which are all based on several cultural values such as sradha and bhakti to God by building praying site, funding religious ceremonies, and ceremonial charity. All of this is the emphasizing on parahyangan concept. Likewise, activities in pawongan concept based on without distinguishing one another since they believe that within human soul there is God who needs to be served, since a good service means that we are trying to bring ourselves near to God. These cultural values in Bali are often to be translated to tatwam asi (respect one another), rwa bhineda (unity in diversity), karmaphala (result and deed), love and olas asih. Palemahan concept also cannot be separated from these values, since when arranging the environment both components are also exist within. Thus, LPD tries to perform THK concept since they cannot be separated from one another.

\section{Summary}

Tri Hita Karana as the reflection of cultural spirituality of Bali society cannot be separated from the locality of agency costs, which has different assumptions to the conventional agency theory. It is obvious in the economic activity of LPD. Agency costs in LPD reflect harmonization between principle and agent that is not based on agency conflict. Principle and agent are both set out harmonization spirit in performing operational financing in LPD.

In general, agency costs expended by LPD are based on indexicality values of THK culture based on religion, which are parahyangan, pawongan and palemahan. Indexicality of parahyangan agency cost is more oriented to the spirituality aspect of Divinity and close to the value aspect. Indexicality brings reflexivity in form of agency cost items such as the development of praying site (pura), ceremonial cost, or charity for ceremonies. Indexicality of pawongan agency cost is more oriented to the harmony in the relationship of humanity. The indexicality brings reflexivity in form of agency cost items such as education, health care, and funeral funds and cost for cultural aspects such as cost for ngaben and nyekah. Indexicality of palemahan agency cost is more oriented to the aspect of harmony with environment. The indexicality brings reflexivity in form of agency costs such as cost for public facilities development that full of environmental harmony.

Cultural values based on religion in LPD are highly needed in order to maintain the business identity in this globalization era. This study surely will give more insight if it is presented in the frame of critical paradigm to see the positive and negative of it from the implementation of modern theory especially agency theory.

[1] Bungin, Burhan. 2007. Qualitative Research Methodology: The Actualization of Methodologist toward Contemporary Variant Variance. Penerbit. Jakarta.

[2] Burrel, Gibson dan Gareth Morgan. 1979. Sociological Paradigms and Organizational Analysis: Elements of the sociology of corporate life. USA: Ashgate Publishing Company.

[3] Chui, Andy C.W., Lloyd, Alison E., Kwok, Chuck C.Y., 2002. The determination of capital structure: is national culture a missing piece to the puzzle? Journal of International Business Studies 33, 99-127.

[4] Chui, Andy C.W., Titman, Sheridan, Wei, John K.C., 2010. Individualism and momentum around the world. Journal of Finance 65, 361-392.

[5] Deal dan Kennedy, 1982, Institutions, financial markets, and firm debt maturity. Journal of Financial Economics 54, 295-336.

[6] Eisenhardt, Katheleen M, 1989, Agency Theory : As Assessment and Review, Academy Management Review, vol.14, No.1, pp. 5774.

[7] Fama, Eugene F., 1980. Agency Problem and The Theory of The Firm, Journal of Political Economy, 38, pp. 288-307.

[8] Fama, Eugene F. dan Michael C. Jensen, 1983. Separations of Ownership and Control, Journal of Law and Economics, vol.27. pp. 301-325. 
[9] Fama, Eugene F. dan Michael C. Jensen, 1985. Disappearing dividends: changing firm characteristics or lower propensity to pay? Journal of Financial Economics, 60, 3-44.

[10] Guiso, Luigi, Sapienza, Paola, Zingales, Luigi, 2008. Social capital as good culture. Journal of the European Economic Association 6, 295-320.

[11] Guiso, Luigi, Sapienza, Paola, Zingales, Luigi, 2009. Cultural biases in economic exchange? Quarterly Journal of Economics 124, 1095-1131.

[12] Hofstede, G. 1990. Measuring Organizational Cultures: A Qualitative and Quantitative Study Acros Twenty Cases, Administrative Science Quarterly; 35, 2; pg. 286

[13] Hofstede, G. 1994. Culture's consequences: International differences in work related values, abridged version. London: Sage.

[14] Hofstede, G, 2001. Culture's Consequences: Comparing Values, Behaviors, Institutions, and Organizations Across Nations (2 ed.). Sage Publications

[15] Huang, Rocco, 2008. Tolerance of uncertainty and the growth of informationally opaque industries. Journal of Development Economics 87, 333-353.

[16] Jensen, Gerald R., Solberg, Donald P., Zorn, Thomas S., 1992. Simultaneous determination of insider ownership, debt, and dividend policies. Journal of Financial and Quantitative Analysis 27, 247-263.

[17] Jensen, Michael C., dan William H. Meckling, 1976, Theory of The Firm: Managerial Behavior, Agency Cost and Capital Structure, Journal of Financial Economics, pp.305-360.

[18] Jensen, M, 1983; Organization Theory and Methodology, Accounting review,pp319-338

[19] Koentjaraningrat. 2005. Cultural mentality dan development, Gramedia Pustaka Utama, Jakarta

[20] Kotter, J.P., and Heskett, SL, 1992, Coporate Culture and Performance. The Free Press. Newyork.

[21] Kotter, J.P., and Heskett, SL, 1997, Coporate Culture and Performance. PT Prehallindo Simon \& Schruster (Asia) Pte.Ltd.

[22] Pemerintah Tingkat I Bali, 2003. Regional Rule No. 12, 2003 on the Carefulness Principle in Managing Village Credit Institution (Lembaga Perkreditan Desa/LPD) in Bali

[23] Poore, Simon. 2000. An ethnomethodology- An introduction. www.hewett.norfolk.sch.uk. Diunduh 3 April 2008.

[24] Sarantakos, Sotirios. 1995. Social Research. Malaysia: Typeset Gallery.

[25] Ramirez, Andres, Tadesse, Solomon A., 2009. Corporate cash holdings, uncertainty avoidance, and the multinationality of firms. International Business Review 18, 387-403.

[26] Riana Gede I, 2010,Application impact of corporate culture THK Orentasi and Orentasi markets and business performance as a result, the doctoral thesis program in Management Sciences, Malang UB graduate school

[27] Robbins, Sthepen, P. 2003, Organizational Behavior, Int. Ed.,Prentice Hall. Ltd., USA.

[28] Robbin, Sthepen, P. 2005, Organizational Behavior, Int. Ed.,Prentice Hall. Ltd., USA.

[29] Ross, 1973, The Economic of Theory Agency: The Principal's Problem; American Economics Review, pp134-139.

[30] Scein, Edgar, H. 2004, Organizational Culture and Leadership,John Wiley and Sont.Inc

[31] Siagian, 2002, .Knowledge Management, Published Kharisma Putra Utama Offset, Jakarta.

[32] Sobirin Ahmad, 2007. Organizational Culture: Definition, Meaning and its Application in Organizational Life, Publisher: UPP STIM YKPN

[33] Tabellini, Guido, 2008. Institutions and culture. Journal of the European Economic Association 6, $255-294$. 